\title{
Environmental Aspects of Using the Electron-Ion Technology in Agriculture of Russia
}

\author{
V. D. Kharitonov ${ }^{1}$, N. S. Nikolaev² \& M. Ya. Burlev ${ }^{1,3}$ \\ ${ }^{1}$ All-Russian Scientific Research Institute of Dairy Industry, Moscow, Russia \\ ${ }^{2}$ Moscow State University of Food Industry, Moscow, Russia \\ 3 JSC “Siberia-Milk", Moscow, Russia \\ Correspondence: M. Ya. Burlev, Zhitnaya str. 10-121, Moscow 119049, Russia. Tel: 7-985-760-8471. E-mail: \\ burlevm@yandex.ru
}

Received: March 29, 2015 Accepted: May 12, 2015 Online Published: June 15, 2015

doi:10.5539/jas.v7n7p223 URL: http://dx.doi.org/10.5539/jas.v7n7p223

\begin{abstract}
Intensification of technological processes, based on the latest achievements of science and technology, is one of the most pressing problems in many sectors of industry - including agricultural process that use the process of dehydration. Technical progress, on one hand, offers possible ways for this problem to be solved - yet on the other it exacerbates the problem, since numerous negative factors become involved. The issue of environmental security equipment and personnel is of particular importance, as well as environmental control in which electric fields are used as a control method.
\end{abstract}

Keywords: ecology in agriculture, electron-ion technology, ozone, electric fields, corona discharge, environmental safety

\section{Introduction}

\subsection{The Background to Research on Environmental Issues in Agriculture}

As well as technical progress that resolves scientific and technological tasks, today's socio-economic situation plays a significant role in setting the requirements for industrial production in the food industry, in agriculture, and in the prospects for their development.

The dehydration process of substances (materials) is widely used - not only in agriculture, but also in the food, chemical, pharmaceutical, medical, wood processing and other industries.

Research on the different energy impacts on substances and materials has shown that electrical technologies have great potential for speeding up the dehydration process. Electron-ion technology deserves special attention, especially the influence of electric fields passing directly through them, or through environments (such as air) around the processed objects.

At the close of the twentieth century, alongside the already-traditional technical uses of electricity in agriculture (industrial equipment, electrical appliances, infrared heating, microwave heating and so forth), a new trend has appeared within the industry, both in Russia and in developed industrial countries, for the use of electron-ion technology. This is based on utilizing the power of an electric field, electric potential and power of interdependent electric charges for the organization of regularized movement of micro particles at a molecular level in solid and liquid substances and materials, with the aim of improving their physical and chemical processes (But, 1992).

Electron-ion technology is an integral part of several applications in physics, and its technology is used in the electrostatic cleaning of gases, electrical separation, convection and contact drying, electrostatics, electrodynamics, refrigeration technology, high voltage engineering, mechanics, gas dynamics, and many others. We're aware each of these areas has great growth potential, but no collective use of these areas has been researched (Ivashov, 1987).

For example, electric separation can be successfully used in the processing of flour, sunflower seeds, and wheat. It is necessary for separating agricultural products from non-ferromagnetic metal impurities, etc. Intensive studies have been made on developing machinery for cleaning seed, based on using corona discharge technology. 
It's been found that in addition to separation processes, a further result of grain handling using electric fields is that flour made from it assumes better bread-baking qualities. However, it should be borne in mind that the process of separation of grain by utilizing corona discharge depends on both humidity and the ambient temperature of the surrounding atmospheric air (Rogov \& Gorbatov, 1974).

Modern industrial electrostatic corona efficiency discharge separators can reach temperatures of $92-98 \%$, with electricity consumption at approximately $0.1 \mathrm{~kW} * \mathrm{~h} / \mathrm{t}$ during the process of separation. This makes for very high efficiency in the cleaning process to remove non-ferromagnetic metal impurities in gelatin production, for example (Rogov \& Gorbatov, 1974).

Scientific publications about electric technology and its various energy impacts have shown that research in the food industry and agriculture must consider not only the benefits, but also the negative impacts of the process (Ilyukhin, 1992; Lipatov \& Kharitonov, 1981; Nikolaev, 2013).

\subsection{The Importance of Environmental Safety}

The most important question is that environmental protection concerning technology and different equipment used in agriculture and the safety of working staff, as well as systematic and continuous control of the environment conditions, where electron-ion technology is in operation.

For example, it is not yet known what the negative effects of electric field radiation may be, in particular corona electrical discharge radiation - and whether it can adversely affect the human body when within range of such radiation.

Little research has been conducted to date on the influence of powerful electric fields during the process of electric impulse induction - specifically concerning adverse effects in both electromagnetic characteristics and also possibly x-ray exposure. This may be due to the ionization of those air components, which characterize the endothermic process with the formation of ions of neutral atoms or molecules.

The Russian scientist Alexander Chizhevsky warned in scientific books and magazines written more than eighty years ago (Chizhevsky, 1959, 1989) about the possible dangers of unsupervised use of various processes, and specifically electric devices he termed "ionizers". In his view, these "were incapable of productively inducing ozone for the treatment of the human body without correct control. Instead they might cause significant damage to people and to the ambient atmosphere air around us".

\subsection{Negative Aspects of Research}

Based on the study and research of the various uses of electric fields in technological processes in different industrial sectors including agriculture - for example, of high-tension electric fields - we can make various deductions about the results of using them.

$>$ The components of the surrounding air show substantial change in their composition. Specifically, these changes include not only ozone gas, but also in the chemical reaction with water vapor during the formation of nitrogen oxides. This causes highly damaging results for the human body, and for the goods produced by the process similarly.

$>$ There has been no study of the effects of static electricity, which arises during the induction of electrical impulses. We should not forget about the ecological damage to atmospheric air, since negative radiation of microscopic substances significantly affects different processes and phenomena around us.

A single cubic meter of atmospheric air contains a substantial number of different microscopic components each of whose structural components, under the influence of corona discharge can become significantly altered at molecular level. It is imperative that we not only carry out such analysis, but also that we list these resulting alterations (List and Codes Ambient Air Pollutants, 1995).

It is vitally important to control the effects on the human body, which might arise from exposure to a high-tension electric field. One form of hemoglobin can be altered (or "oxidized") as we know that oxidization can occur. This is due to the impact of nitric oxide (a form of nitric acid), which affects the nervous system, the respiratory tract and the mucous membranes of the eye (Glushchenko, 1988).

In addition, if you follow the logic of this further, a similar hypoxial denial of oxygen might occur to microscopic organism fauna and flora, as well as or even to the organisms of domestic pets.

It needs to be borne in mind that an increased content of ozone in the atmospheric layer - for example, in premises where animal feeding occurs, or in the processing of agricultural raw materials - may adversely affect elements of the process management system. 


\subsection{Positive Aspects of Research}

However, some benefits arise from using a high-tension electric field in industrial environments, in agriculture, in the food industry, in medicine, in the pharmaceutical industry, and other areas (Novitskaya, 2009; Burlev, 2012).

For example, the introduction of ozone, as a component with an electric potential of powerful impact on atmospheric air, can be put to beneficial use.

$>$ Ozone is approximately 300 times faster than other disinfectants, and can destroy all microscopic organisms known in nature;

> Ozone is a reliable disinfectant and can deployed in any kind of technological production;

$>$ Ozone is effective over short time intervals;

$>$ Ozone is an effective "deodorant";

$>$ Ozone doesn't affect the "ph" of $\mathrm{H}_{2} \mathrm{O}$ negatively, nor does it synthesize negative environmental components from water molecules;

$>$ Ozone doesn't form toxic by-products and is transformed at the molecular level in $\mathrm{O}_{2}$;

$>$ Ozone can be produced very simply, without requiring storage and transport in industrial conditions (Burlev, 2004).

The result of ozonisation of air significantly reduces the number of viruses and germs, so that the shelf life of different substances - including foods - is significantly increased.

\section{Research}

The facilities at the laboratories of Moscow State University have been carrying out research for more than twenty-five years on the use and industrial application of electron-ion technology for improving technological processes by processing various substances. This research specifically studied the negative effects on ambient air during the process of electric corona discharge (Burlev, 2013).

For example, the Moscow Scientific Research Institute of Epidemiology and Microbiology laboratory studied animal blood samples related to the production of medicines and micro biocides drugs. Air treated by corona discharge was passed through the blood of the animal (blood sparging). The liquid component of blood changed color, becoming almost discolored due to destruction of the red blood cells. This process occurred within 10-15 minutes.

Conclusions: the sensitivity level of blood exposed to the air from field of corona discharge is greatly increased. This is one of the most significant negative factors of electric "Corona" discharge on the organisms of humans and animals.

Professor G. K. Berman - Doctor of Technical Sciences at the "Scientific Research Institute of Rubber and Latex" in Moscow, Russia - also conducted studies on the influence of electric field during drying processes latex. He found that air that underwent electric corona discharge for 7-8 minutes destroyed the surface layer of samples of latex, and formed deep cracks throughout the volume of the latex. This means that nitric oxide caused the degradation of the polymer latex (Berman, 2001).

German scientific and technical publications (Lang, 1978) report that State laws of the Federal Republic of Germany prohibit the use of such gases as ozone during the processing of foodstuffs - particularly meat products, and semi-finished products. The bottom line is that significant changes occur in the characteristics of these meats and minced meat products. The use of ozonized air induces a bright colour of red on the surface of the meat, along with a false perception by buyers that these meat products are absolutely fresh.

Therefore, the use of a corona discharge electric field is not only unacceptable from an environmental point of view, but also from a safety viewpoint. Furthermore and as described above, contact with air treated by corona discharge for a food product is undesirable - due to the oxidation of fats, due to the impact of nitrogen oxides, ozone, nitrogen and other synthesized acids.

The corona discharge emitted by electrical equipment can distort industrial radio frequency waves (Ilyukhin, 2005). Currently, almost every area of industry uses large numbers of high-precision electronic devices which cause risk effects due to electromagnetic radiation, sources of radio engineering and electronic devices, inductors, transformers, fluorescent and incandescent light bulbs, antennas, high-frequency generators and other devices. (Novikov, 2005). 


\section{Options for Dealing with the Environmental Challenges}

Protective Screens are the front line of defense in cases of electric field radiation. They can be designed to be used in combination (in the form of a Cascade), or be manufactured to meet the needs of individual projects. Cascading screens have body sections made of mesh metal frame. Even so, they must be installed in accordance with safety requirements by qualified personnel (Leb, 1963). The second type of screening is the insulation of high-voltage equipment by installing it in a separate room with a remote control.

If the operating conditions of the high-voltage equipment in different areas are not subject to regulatory control, then the following options should be considered when deploying protective systems:

$>$ A system of high-protection screens should be installed for protective purposes in all locations where high voltage equipment is in operation;

> High-voltage equipment should be kept at a distance from other technical installations;

> Organizational processes need to be used to control the distribution of equipment in industrial plants;

$>$ Staff should be provided with individual safety equipment and procedures;

$>$ A cascading protection system should be used to reduce the impact of radiation from high-voltage equipment;

> Automated remote control should be used to regulate technological equipment in risk areas;

> The "faraday cell" method should be used to protect devices from the effects of radiation (Tager, 1968).

\section{Conclusions}

More research is needed to study radiation from high voltage equipment. Protection of this equipment and its operating personnel from such radiation requires particular attention, in order to secure the entire production systems in numerous industries - including agriculture. Ongoing research is essential to ensure the safety of working conditions and of the environment. The Montreal Protocol on Substances that Deplete the Ozone Layer came into force on January 1, 1989. This International Protocol is designed to protect the ozone layer. Industrial processes, which deplete the ozone layer, must be listed for phasing-out.

\section{References}

Berman, G. K. (2001). Method of manufacture latex products. Patent No. 1349227 (Russian Federation). In G. K. Berman, E. A. Belder, V. S. Yershov, V. V. Ilyukhin, B. A. Majzelis, A. A. Pepeliaev, Yu. D. Onishchenko, V. P. Starun \& A. V. Ivanov (Eds.), Inventions and utility models (No. 35). Moscow.

Burlev, M. Ya. (2004). Environmental aspects of the use of corona discharge in processing agricultural raw materials. In M. Ya Burlev, V. V. Ilyukhin, S. S. Ilyukhina, N. V. Makarov, I. M. Tambovcev \& S. V. Shishkin (Eds.), Energy efficiency in processing sectors of the agro-industrial complex (pp. 50-55). Moscow.

Burlev, M. Ya. (2012). Aspects of the use of electron-ion technology in medicine, pharmacy and veterinary medicine. Biomedical and Biosocial Anthropology Journal of the International Academy of Integrative Anthropology Founded Vinnitsa National Pyrogov Memorial Medical University, 19, 45-48.

Burlev, M. Ya. (2013). Aspects of electron-ion technology in industry (p. 63). In M. Ya. Burlev, V. V. Ilyukhin \& N. S. Nikolaev (Eds.), Verlag LAP LAMBERT Academic Publishing, AV Akademiker-Verlag GmbH \& Co. KG. Saarbrücken, Deutschland.

But, A. I. (1992). Electron-ion water structures processes of living organisms and their products (p. 150). Moscow.

Chizhevsky, A. L. (1959). Application guide of ionized air in industry, agriculture and medicine (p. 57). Gosplan: Publishing House.

Chizhevsky, A. L. (1989). Air ions and life (pp. 322-344). Moscow: Thought-Publishing House.

Glushchenko, N. A. (1988). Basic theory and practice of electric aeration solutions in food biotechnology (p. 44). Techn. of Sciences. Moscow.

Ilyukhin, V. V. (1992). Drying using the electron-ion technology. In V. V. Ilyukhin, \& M. Ya. Burlev (Eds.), Dairy Industry (No. 3, pp. 41-44). Moscow.

Ilyukhin, V. V. (2005). Industrial radio interference from the electrical equipment of the AIC. In V. V. Ilyukhin, M. Ya. Burlev, I. M. Tambovcev, S. V. Shishkin \& S. S. Ilyukhina (Eds.), Reliability and technical 
diagnostics equipment processing industries of agro-industrial complex (pp. 137-141). Techn. Sciences, Moscow.

Ivashov, V. I. (1987). Laboratory workshop for student (pp. 60-75). In V. I. Ivashov, S. G. Yurkov, V. V. Ilyukhin, B. N. Dujdenko \& V. A. Katuyhin (Eds.), Moscow Technology Institute Meat and Milk Industry.

Lang, O. (1978). Vermeidung von Gewichtsverlusten beim Kuhlen und Gefrieren von Fleisch. Die Fleischwirtschaft, 3, 402-405.

Leb, L. (1963). Static electrization (p. 408). Moscow: Energy Publishing House.

Lipatov, N. N., \& Kharitonov, V. D. (1981). Milk Powder (p. 263). Moscow: Light and Food industry.

List and Codes Ambient Air Pollutants. (1995). St. Petersburg. p. 137.

Nikolaev, N. S. (2013). Mathematical Modeling of the Process of Convective Drying of Skim Milk Using and Electric Field. In N. S. Nikolaev, M. Ya. Burlev \& M. A. Uryupin (Eds.), Russian Agricultural Science (Vol. 39, No. 5-6, pp. 526-528). Allerton Press Inc., USA. http://dx.doi.org/10.3103/s1068367413060141

Novikov, Yu. N. (2005). Electrical and Electronics engineering (p. 380). Moscow: Science.

Novitskaya, N. S. (2009). Application of ozone technology in the processing of milk. Processing of Milk, 10, 54-55.

Rogov, I. A., \& Gorbatov, A. V. (1974). Physical methods food processing (pp. 462-465). Moscow: Food industry.

Tager, A. A. (1968). Physic-Chemistry of polymers (p. 536). Moscow: Chemistry.

\section{Copyrights}

Copyright for this article is retained by the author(s), with first publication rights granted to the journal.

This is an open-access article distributed under the terms and conditions of the Creative Commons Attribution license (http://creativecommons.org/licenses/by/3.0/). 